\title{
BEYOND LAWFARE: JURIDICAL OVERSIGHT OF WESTERN MILITARIES
}

\author{
CHRISTOPHER WATERS*
}

While civilian supremacy over the armed forces is accepted as a matter of faith in Western countries, this supremacy often means little more than supremacy of the executive branch of government over top generals. Indeed, efforts to regulate armed forces through broader domestic or international legal frameworks, including international criminal law, have been resisted in some military quarters (particularly in the United Kingdom and the United States) with the military and its backers raising concerns of "legal encirclement" or "lawfare." The author argues for broad civilian and democratic oversight of armed forces, including through increased judicial and quasi-judicial scrutiny of overseas military actions at the domestic and international levels. The author concludes that broad democratic oversight not only promotes compliance with international legal norms but supports operational effectiveness as well.

\begin{abstract}
Alors que l'on accepte la suprématie civile sur les forces armées comme une question de confiance dans les pays occidentaux; cette suprématie reflète souvent seulement la suprématie de l'autorité exécutive sur les généraux du plus haut niveau. En effet, l'effort fait pour réguler les forces armées au moyen de cadres juridiques intérieurs et internationaux plus larges, incluant le droit pénal international, a fait l'objet d'opposition dans les milieux militaires (surtout au Royaume-Uni et aux États-Unis), les militaires et leurs partisans invoquant des inquiétudes à l'égard d'un «encerclement juridique» ou «lawfare», néologisme pouvant se traduire par «l'utilisation du droit comme arme de guerre». L'auteur milite pour une vaste surveillance civile et démocratique des forces armées, incluant un examen étude judicaire et quasi-judiciaire plus minutieux, aux niveaux national et international, des actions militaires à l'étranger. L'auteur conclut qu'une vaste surveillance démocratique n'encourage pas seulement le respect des normes juridiques internationales, mais va aussi dans le sens d'une efficacité opérationnelle.
\end{abstract}

\section{TABLE OF CONTENTS}

I. INTRODUCTION $\ldots \ldots \ldots \ldots \ldots \ldots \ldots \ldots \ldots \ldots \ldots \ldots \ldots \ldots \ldots \ldots$

II. Democrats, JUdGeS, AND SOLDIERS $\ldots \ldots \ldots \ldots \ldots \ldots \ldots \ldots . \ldots 86$

III. KeEPING LegalizATION AT BAY:

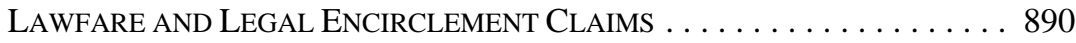

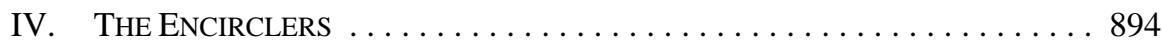

V. LAWFARE AND THE LIMITS OF OVERSIGHT $\ldots \ldots \ldots \ldots \ldots \ldots \ldots . \ldots 96$

A. Civilianization and its Benefits $\ldots \ldots \ldots \ldots \ldots \ldots \ldots . \ldots . \ldots 96$

B. THE WEAK CHECK OF INTERNATIONAL HUMANITARIAN LAW . . . 899

C. Courts ARE Deferential to War Fighting . . . . . . . . . 901

VI. RETHINKING Civil-MilitaRy ReLATIONS:

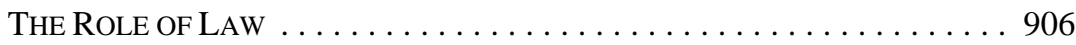

VII. Conclusion $\ldots \ldots \ldots \ldots \ldots \ldots \ldots \ldots \ldots \ldots \ldots \ldots \ldots \ldots \ldots \ldots \ldots \ldots$

Associate Dean, Faculty of Law, University of Windsor. I thank Christina Beninger and Ugo Popavic for their research assistance and the participants in the 2008 "Four Societies" conference for their helpful comments on an earlier draft. I would also be remiss if I did not thank the numerous British (at the Joint Services Command and Staff College) and Canadian (at the Pearson Peacekeeping Centre and RMC Saint-Jean) officers who have openly and intelligently engaged with me on some of the ideas reflected in this article over the last decade. Finally, the financial support of the Law Foundation of Ontario is gratefully acknowledged. This article is current to November 2008. 


\section{INTRODUCTION}

The armed forces require trust and loyalty between those commanding and those being commanded, they require strict discipline over matters not within the purview of a civilian employment relationship, and they require the will to fight and win. It has been suggested by many in the military and their supporters that thick, civilianized, regulation of the armed forces is anathema to operational requirements and the military ethos. In the United Kingdom, a rallying cry among some senior officers, politicians, and the media has been "legal encirclement" or "legal siege." 1 Particularly, the potential purview of the International Criminal Court (ICC) has triggered invective and it has been suggested that British troops are second-guessing themselves in combat situations for fear of prosecutions. In the United States, similar concerns about the law have been collected under the rubric of "lawfare." The term gained currency post-9/11 and primarily refers to attempts by enemies of the U.S. projection of power to use law to discipline and hamper that power. ${ }^{2}$ Legal attacks on military courts established to try detainees at Guantanamo Bay, for example, have been included within the ambit of lawfare. ${ }^{3}$ Taking the need for democratic governance as its starting point — and the importance of judicial and quasi-judicial oversight of the military as central to that governance - this article critically evaluates the lawfare and legal encirclement claims. It also briefly inquires into why these claims have been largely absent from the discourse on civil-military relations in Canada.

\section{DEMOCRATS, JUDGES, AND SOLDIERS}

At least since Plato's concern with guarding against the guardians, thinkers, politicians, and soldiers have queried why, and in what circumstances, those with weapons would obey those without weapons. In some countries — in August 2008 Mauritania suffered its second coup in three years - the Praetorian threat remains a fact of life. In point of fact, however, the number of military dictatorships worldwide is at historically low levels, even if military interference in politics is still common. ${ }^{4}$ Certainly in Western democracies, democratic and civilian control over the military is accepted as an article of faith. Politicians appoint top commanders, civilian control is taught in military academies, and the military only intervenes internally in cases of emergency and then only at the request of civilian authorities. Of course, there are modern examples in the Western security space that warn against complacency in this regard - French military intervention in government at several points in the twentieth century and the sabre-rattling of secularist Turkish generals today spring to mind $^{5}$ — but a coup in London, Ottawa, or Washington is not in the cards. Indeed, civilian

1

See e.g. Jenny Booth, “Military Top Brass Attack Soldier Prosecutions” Times Online (14 July 2005), online: Times Online <http://www.timesonline.co.uk/tol/news/uk/article544087.ece>. See also U.K., H.L., Parliamentary Debates, vol. 673, col. 1236 (14 July 2005) [H.L.].

2 See Charles J. Dunlap, Jr., “It Ain’t No TV Show: JAGs and Modern Miltary Operations” (2003) 4 Chicago J. Int'l L. 479.

3 Michael J. Frank, “U.S. Military Courts and the War in Iraq” (2006) 39 Vand. J. Transnat'l L. 645.

$4 \quad$ Thomas Bruneau \& Harold Trinkunas, "Democratization as a Global Phenomenon and its Impact on Civil-Military Relations” (2006) 13 Democratization 776 at 777.

5 On the French example see Pascal Vennesson, "Le soldat et le politique: du coup d’État au contrôle démocratique” in Gérard Varenne, ed., Les armées en questions (Paris: Economica, 2005) 41. On the Turkish situation see Steven A. Cook, “The EU, Erdogan and Turkey’s Generals” International Herald Tribune (23 April 2007), online: Council on Foreign Relations <http://www.cfr.org/publication/13157 
control over the military is a precondition to get into Western clubs, including the European Union (EU) and the North Atlantic Treaty Organization (NATO), and can be a condition of foreign aid. ${ }^{6}$ This of course does not mean that the question of civilian control over the military is a non-issue in the West. The poignant question being asked today is not whether the military will take over, but rather, what is the appropriate relationship between the civilian authority and the military? These questions reach the public eye on occasion. Former Secretary of Defence Donald Rumsfeld's poor relationship with his commanders has been dissected by a media still mindful of episodic civilian-military wrangling during the Korean and Vietnam wars. And, in Canada, while service records and military savvy are less important assets for politicians than south of the border, speculation about a rift between then Chief of the Defence Staff Rick Hillier and his political masters over Afghanistan policy, and the politics of choosing Hillier's successor, have both been the subject of media scrutiny. ${ }^{7}$

Civil-military relations have been tackled through a variety of theoretical lenses across disciplines such as military sociology and democratic theory. However, the most common post-war paradigm, and still the starting point for most military discussions of the topic, is that put forward in Samuel P. Huntington's The Soldier and the State. ${ }^{8}$ Huntington viewed the military and civilian spheres as inherently in opposition; one conservative and realist, the other liberal and idealistic. Rather than seeking to narrow that functional and cultural gap, the ideal for Huntington was a clear differentiation between the military and civil spheres. He advocated for an autonomous and professionalized military, with civilian authorities setting only strategic direction, allowing the military to get on with the rest, as the best way to create an apolitical military that would direct its energies against an external enemy. Another seminal work of the early Cold War period, Morris Janowitz's The Professional Soldier, took an opposite view. In contrast to Huntington's focus on the differentiation of tasks between civil and military spheres, it suggested that professional socialization of the military through its relationship with and understanding of civilian society was the way to ensure effective civilian control over the armed forces and military effectiveness. ${ }^{9}$ In Janowitz's “constabulary” model, inefficient friction is more likely to foment between the two spheres when they are poorly integrated.

Many since Huntington and Janowitz have gone beyond the issue of the Praetorian threat and, taking civilian control of the military as a starting point in mature democracies, ask questions about how the civilian executive can effectively manage the relationship by defining alternatives and the terms of debate. ${ }^{10}$ As Don Fernando puts it in the Cid, "Thus your reasoning is not reasoning for me. You speak as a soldier — I must act as a king."11 Today the civilian executive, rather than the king, must manage a large and complex institution with its own institutional language, goals, culture, and procedures that may or may

/eu_erdogan_and_turkeys_generals.html>.

Bruneau \& Trinkunas, supra note 4 at 776.

See Tonda MacCharles, “PM defends ‘Outstanding’ Chief of Defence Staff” Toronto Star (4 October 2007), online: Toronto Star <http://www.thestar.com/News/article/263527>. (Cambridge: Belknap Press of Harvard University Press, 1957). 
not correspond with a government's domestic or foreign policy tone or agenda. One of the more persuasive and influential post-Cold War accounts of civilian management of the military is Peter Feaver's agency theory. ${ }^{12}$ Feaver suggests that civil-military relations can be seen as a series of strategic interactions typical to other principal-agent relationships. Rather than issuing a direct challenge to a principal (the civilian executive), the agent (the military) in mature democracies will work or shirk (by exaggerating costs or difficulties to political masters) depending on the institutional goals of the agent itself. This theory and others are undoubtedly useful in understanding the nature of civil-military relations. However, management and agency accounts of the civilian-military relationship are limited in that they usually equate "civilian” control with "civilian executive” control.

A new generation of scholars whose writings have appeared in the last decade or so have been less concerned with effective management of the military by a civilian executive, in other words the interaction between ministers of defence and top generals, and more focused on a broader understanding of democratic governance over the security sector. ${ }^{13}$ The main project of this newer movement is to view oversight of the military through the lens of the legislative as well as the executive branches of government and indeed to reinvigorate parliamentary scrutiny over the executive on security matters. ${ }^{14}$ Parliamentary control over troop deployments for combat is seen as a crucial democratic check on executives. Such control may be especially important in deployment roles, like peacekeeping, because such operations tend to have a minimal impact on voters' decisions. In such cases, it has been argued, "parliaments are the central locus of accountability for any governmental decisionmaking concerning the use of force." 15 The need for legislative oversight to avoid "legal black holes" has also been argued in the context of the "war on terror."16 In point of fact, in several Western democracies, including Canada, troop deployment remains a matter for the executive in constitutional terms. At best, in these countries, it may be said that parliaments are gradually asserting themselves in a more formal role in troop deployments. ${ }^{17}$ The Canadian government has agreed, for example, to seek Parliamentary approval for troop deployments in Afghanistan, but this is not as a matter of general policy. ${ }^{18}$ Another focus of the democratic governance school has been on the democratic deficits left by the internationalization of use of force commitments. Inter-state executive level negotiations over

Peter D. Feaver, Armed Servants: Agency, Oversight and Civil-Military Relations (Cambridge: Harvard University Press, 2003).

Andrew Cottey, Timothy Edmunds \& Anthony Forster, "The Second Generation Problematic: Rethinking Democracy and Civil-Military Relations” (2002) 29 Armed Forces \& Society 31 at 31-32. Ibid. at 39.

Heiner Hänggi, "The Use of Force Under International Auspices: Parliamentary Accountability and 'Democratic Deficits'” in Hans Born and Heiner Hänggi, eds., The 'Double Democratic Deficit': Parliamentary Accountability and the Use of Force Under International Auspices (Aldershot: Ashgate, 2004) 3 at 11.

16 Andreas Paulus \& Mindia Vashakmadze, "Parliamentary Control Over the Use of Armed Forces Against Terrorism - In Defence of the Separation of Powers” (2007) 38 Netherlands Yearbook of International Law 113 at 154 .

17 See generally, Parliamentary Information and Research Service, International Deployment of Canadian Forces: Parliament's Role by Michael Dewing \& Corinne McDonald (Ottawa: Library of Parliament, 2006), online: Parliament of Canada <http://www.parl.gc.ca/information/library/PRBpubs/prb0006e.htm>.

On the government's Afghanistan troop deployment pledge, see "Speech from the Throne to Open the Second Session Thirty-Ninth Parliament of Canada" (16 October 2007), online: Parliament of Canada <http://www2.parl.gc.ca/parlinfo/documents/ThroneSpeech/39-2-e.html>. 
military commitments shut legislators out of information sharing and concession-making and result in commitments that are politically hard to break. Thus, for example, some observers have argued that the decision-making by military, diplomatic, and ministerial elites under the auspices of a common European Security and Defence Policy or the NATO create a "democratic deficit."19 Indeed, several NATO member states did not seek parliamentary approval before authorizing bombing raids on Serbia in the 1999 Kosovo campaign.

Democratic deficits in civilian control over the military are considered worrying for two primary reasons. The first has to do with the health of democracy itself, especially as democratic control of security and defence policy may be considered core functions of a democracy. Executive capture of a security agenda has an impact on budgets, civil liberties, and, quite obviously, the lives of young people in the armed forces. The second reason taps into the idea of a "democratic peace," around since at least Immanuel Kant and empirically demonstrated in recent decades, which suggests that democracies are less likely to go to war, at least with each other, than authoritarian states. ${ }^{20}$ Another explanation is that "the participatory nature of the states' political institutions constrain leaders because the populations who must bear the costs of war may be unwilling to do so if the costs are high or the policy fails." ${ }^{21}$ To these two explanations, generally offered by the democratic governance school, I would tentatively (since the instrumentalism of this argument presents obvious dangers) add another, one that has the benefit of appealing to military, as well as civilian, stakeholders. As will be discussed below, it is my argument that militaries in democracies are more effective than those in other regime types - they are better at winning wars.

As noted in the introduction, this article takes the "democratic governance" school of civil-military relations as a starting point. However, while the executive and legislative branches of government have been comprehensively studied with respect to scrutiny of the military, the judicial branch has not. ${ }^{22}$ Thus, this article attempts to tackle the relatively

Wolfgang Wagner, “The Democratic Control of Military Power Europe” (2006) 13 Journal of European Public Policy 200.

Generally speaking, the empirical basis for this claim is accepted, though see Sebastian Rosato, "The Flawed Logic of Democratic Peace Theory” (2003) 97 American Political Science Review 585. A riposte to Rosato can be found in David Kinsella, "No Rest for the Democratic Peace" (2005) 99 American Political Science Review 453. Arguments about whether democratic states have a propensity to overt and covert intervention in semi- or non-democratic states are more contentious: see Charles W. Kegley, Jr. \& Margaret G. Hermann, "How Democracies Use Intervention: A Neglected Dimension in Studies of the Democratic Peace” (1996) 33 Journal of Peace Research 309.

Randolph M. Siverson, "Democracies and War Participation: In Defense of the Institutional Constraints Argument” (1995) 1 European Journal of International Relations 481 at 482. Some authors have attempted to go beyond the focus on formal regime type in examining propensity for intervention and war. For a recent, comparative look at the effect of military influence on conflict propensity among democratic regimes, see Seung-Whan Choi \& Patrick James, "Civil-Military Structure, Political Communication, and the Democratic Peace” (2008) 45 Journal of Peace Research 37.

I hesitate to invoke the separation of powers paradigm, however, since it is usually applied only to legislative or judicial scrutiny of the executive "war power." The current enterprise is broader in that it also looks at what scrutiny the judiciary exercises over the military in the latter's capacity as a distinct actor. Furthermore, a doctrine of separation of powers, it has been suggested, is conceptually problematic in the sphere of international judicial scrutiny of the behaviour of states and international organizations, given the role that sovereignty continues to play in international law: see Christian Tomuschat, "International Law: Ensuring the Survival of Mankind on the Eve of a New Century” (1999) 
neglected question of oversight of the military from judicial and quasi-judicial (ombudsmen, coroners, etc.) bodies. Looking at the recent experience of the U.K., the U.S., and Canada in relation to domestic, regional, and international tribunals, this article will probe the extent to which there is civilian judicial oversight over military action when those states' forces are engaged overseas. In doing so, the article will address the applicability of human rights and international criminal legal regimes, as well as the availability of enforcement mechanisms, to the military. Does, for example, the Convention for the Protection of Human Rights and Fundamental Freedoms (via the Human Rights Act 1998) apply to the actions of British soldiers on routine patrol in Iraq? ${ }^{23}$ Does the Canadian Charter of Rights and Freedoms ${ }^{24}$ apply to the actions of Canadian soldiers who detain Afghan citizens and hand them over to local authorities? This article will also go beyond formal law and take a socio-legal look at the reaction of militaries to "creeping civilianization." To put it briefly, this form of legalization and civilianization has recently been considered a threat to morale and operational effectiveness and has spawned the lawfare and legal encirclement notions mentioned in the introduction. ${ }^{25}$

Intriguingly, in Canada, broad civilian oversight of the armed forces both at home and abroad appears to be largely accepted as a general principle, at least to a greater extent than in the U.K. and U.S. For example, while criticism of the Canadian Forces Afghan detainee policy has been played down as a "distraction" by top brass, there has not been the visceral reaction in Canada against civilian oversight over the conduct of operations. ${ }^{26}$ This is very likely a result of changes to institutions and Canadian military culture that took place following the Somalia debacle and subsequent fallout. This article will argue that the rise in "legal encirclement" and "lawfare" claims in the U.K. and U.S. represent misguided and dangerous attempts to resist civilian/democratic oversight and juridical oversight in particular.

\section{KEEPING LEGALIZATION AT BAY: LAWFARE AND LEGAL ENCIRCLEMENT CLAIMS}

It is difficult to say who coined the term "lawfare.” Different people appear to have come to it independently. ${ }^{27}$ For present purposes, however, the relevant starting point is 9/11 and the subsequent "war on terror." It is in this context that U.S. military and national security action has been challenged through the application of legal norms, in terms of humanitarian and human rights law and in terms of the jus ad bellum. Col. Charles Dunlap, a U.S. Air

281 Rec. des Cours 9 at 25.

23 Convention for the Protection of Human Rights and Fundamental Freedoms, 4 November 1950, 213 U.N.T.S. 221 [ECHR]; Human Rights Act 1998 (U.K.), 1998, c. 42 [Human Rights Act].

$24 \quad$ Part I of the Constitution Act, 1982, being Schedule B to the Canada Act 1982 (U.K.), 1982, c. 11 [Charter].

25 On legalization, see Judith Goldstein et al., "Introduction: Legalization and World Politics” (2000) 54 International Organization 385. The legalization concept is returned to below.

$26 \quad$ Meagan Fitzpatrick, "Hillier Calls Prisoner-Abuse Allegations a Needless Distraction for Canadian Troops in Afghanistan” Ottawa Citizen (2 May 2007), online: Ottawa Citizen <http://www2.canada. com/ottawacitizen/news/story.html?id=11d43f66-aed4-4ab8-877b-fa2dd2593766\&k=52311>.

27 One of the earliest examples is John Carlson \& Neville Yeomans, "Whither Goeth the Law — Humanity or Barbarity” in Margaret Smith \& David Crossley, eds., The Way Out: Radical Alternatives in Australia (Melbourne: Lansdowne Press, 1975). 
Force lawyer (and now Major General and Deputy Judge Advocate General) is often attributed authorship of the term, beginning with a November 2001 essay for Harvard's Carr Center for Human Rights Policy. In that essay he asked:

Is warfare turning into lawfare? In other words, is international law undercutting the ability of the U.S. to conduct effective military interventions? Is it becoming a vehicle to exploit American values in ways that actually increase risks to civilians? In short, is law becoming more of the problem in modern war instead of part of the solution? ${ }^{28}$

In this and subsequent writings, Dunlap presents law's prevalence as a feature of the twentyfirst century war and indeed a weapon in these modern wars. More specifically, he describes lawfare as attempts by opponents of the U.S. projection of power to use law to discipline and hamper that power. ${ }^{29}$ Legally informed strategies are asymmetric tools of the weak to be used against militarily superior forces and military commanders, and civilian masters need to be aware of and on guard against these weapons. The most concrete and least controversial use of the term, one that is not addressed in this article, describes the use of protected persons or places by fighters to shield themselves from attack from an enemy who has greater firepower but is constrained by international humanitarian law (IHL) norms. More expansively, lawfare is used to describe a variety of legal weapons challenging American might. Thus, challenges to the legality of U.S. military tribunals to try terrorism-related charges, the referral of cases to international courts, and the treaty to ban cluster munitions have all been described as examples of lawfare in action. ${ }^{30}$ Lawfare is not the only word that has been deployed to describe the use of law against the U.S. military. "Hyperlegalism"31 and "martial litigation"32 have been suggested as well. It should also be pointed out that the wagers of lawfare are not limited to foreign "Islamists" and other obvious enemies. Americans themselves who use the courts to oppose what they see as draconian abuses of civil liberties in the war on terror have been described as "misusing" the legal system. International or transnational actors, including the International Committee of the Red Cross (ICRC), Human Rights Watch, and even the International Court of Justice itself (as a result of the Palestinian Wall Advisory Opinion) have also been accused of lawfare. ${ }^{33}$ Implicitly, lawfare even made it into the 2005 U.S. National Security Strategy: "Our strength as a nation state will continue to be challenged by those who employ a strategy of the weak using international fora, judicial processes, and terrorism."34

Charles J. Dunlap Jr., "Law and Military Interventions: Preserving Humanitarian Values in 21st Century Conflicts” (Paper prepared for the Carr Centre for Human Rights Policy, 29 November 2001), online: Harvard Kennedy School < http://www.hks.harvard.edu/cchrp/Web\%20Working\%20Papers/Use\%20of \%20Force/Dunlap2001.pdf $>$.

Dunlap, supra note 2.

See e.g. Frank, supra note 3.

See Richard K. Betts, “Compromised Command: Inside NATO’s First War,” Book Review of Waging Modern War: Bosnia, Kosovo, and the Future of Combat by Wesley K. Clark, (2001) 80 Foreign Affairs 126 at 129.

$32 \quad$ Frank, supra note 3 at 648.

33 See e.g. Jeremy Rabkin, “'Lawfare’: The International Court of Justice Rules in Favor of Terrorism” The Wall Street Journal (17 July 2004), online: The Wall Street Journal <http://www.opinionjournal. com/forms/printThis.html?id=110005366>.

$34 \quad$ Department of Defense, National Defense Strategy Of The United States Of America (18 March 2005) at 5, online: Global Security <http://www.globalsecurity.org/military/library/policy/dod/d20050318 ndsl.pdf>. 
More recently, Dunlap's early defensive view of lawfare has been supplemented by a dynamic, multi-dimensional version. In this version, rather than being solely on the receiving end of lawfare, militaries and their political masters use law strategically by justifying actions through an enabling legal framework. Lawfare becomes, in this view, a neutral plane simply a feature of twenty-first century warfare - that can be used by any party to greater or lesser effect. Human rights norms might provide the cloak for aggression, but they might equally provide a weapon against such aggression. Civilian casualties may be portrayed as the direct result of a failure to protect civilians or cast as the unfortunate, but inevitable, outcome of a proportionate attack on a military object. As David Kennedy puts it in Of War and Law, "[l]aw now offers an institutional and doctrinal space for transforming the boundaries of war into strategic assets, as well as a vernacular for legitimating and denouncing what happens in war." 35 In his view the humanitarian and the soldier have moved closer together into a mutual legal space where the same language and norms are used to defend and attack military initiatives. Judging by the voluminous positive reviews of Kennedy's book, including a "blurb” on the book cover by Dunlap himself, this expansive view of lawfare has been well-received in U.S. defence studies circles.

On the other side of the Atlantic, the term lawfare has not gained popularity in the British military or among its supporters. Despite the number of combined operations and the strong influence of American strategic and tactical thinking on the British military, the "Neo-Con" undertones to lawfare simply do not resonate in the U.K. in the same way. However, some similar complaints have been made in the U.K. as in the U.S. and to these have been added concerns about legalization and over-regulation generally. Several former chiefs of defence staff have expressed dismay about the "legal encirclement" or "legal siege" of the British armed forces. ${ }^{36}$ Admiral Lord Boyce, Chief of Defence Staff at the time of the 2003 Iraq invasion, is a particularly vocal critic of the perceived encroachment of law and resulting harm to operational effectiveness. As he put it in the House of Lords:

The Armed Forces are under legal siege... They are being pushed by people schooled not in operations but only in political correctness. They are being pushed to a time when they will fail in an operation because the commanding officer's authority and his command chain has been compromised with tortuous rules not relevant to fighting and where his instinct to be daring and innovative is being buried under the threat of liabilities and hounded out by those who have no concept of what is required to fight and win. ${ }^{37}$

35 David Kennedy, Of War and Law (Princeton: Princeton University Press, 2006) at 116.

36 Booth, supra note 1. A more detailed account of what is meant by "legal encirclement” in the United Kingdom can be found in Christopher P.M. Waters, “Is the Military Legally Encircled?” (2008) 8 Defence Studies 26.

$37 \quad$ H.L., supra note 1. 
These comments have been echoed in official military publications (albeit in less political language $),{ }^{38}$ by politicians of both major political parties ${ }^{39}$ and media commentators. ${ }^{40}$

A sense of legal encirclement is also evident among ordinary officers and enlisted personnel. This is evident through a quick survey of internet chat forums such as the British Army Rumour Service (ARRS), where resentment about the trials of British soldiers has been expressed, and is suggested by the recent creation of the British Armed Forces Federation, which promises legal support to members. ${ }^{41}$ Some useful empirical data on the subject has recently been gathered by a British Army officer using an anonymous web survey of British military personnel as part of a masters dissertation. ${ }^{42}$ One proposition posed by the survey was as follows: "I believe that recent changes to UK law (incorporating legislation from the International Criminal Court) are damaging the operational effectiveness of units on operations." ${ }^{23}$ Forty-three percent of respondents across the three services believed that effectiveness had indeed been damaged. ${ }^{44}$ For the army, the figure was 50 percent. A staggering 77 percent of all respondents (82 percent in the army) were of the view that "[m]ilitary commanders and their subordinates are much more likely to be investigated and charged with war crimes than ever before." ${ }^{\text {"4 }}$ Forty-three percent (50 percent in the army) found that the "utility of mission command had been significantly reduced" because of this greater likelihood of prosecution. ${ }^{46}$ Differences in perception between the services - with the army feeling most at risk - may be explained, in part at least, by the fact that soldiers dealing with insurgents and civilians in Iraq and Afghanistan are most likely to feel legal pressure on a daily basis.

However, in addition to apprehensiveness about the law, the data from this survey also shows interest in law and a desire to comply with legal norms. An overwhelming number of participants in the survey, for example, agreed that "[m]ilitary commanders at all levels should take more care to consider the legal implications of any mission or task they have

See e.g. Pat Conn, The Military Covenant, online: The Airborne Network <http://www. abnetwork.org/articles/military-covenant/militarycovenent2.htm>. The Covenant states that "[b]y placing more emphasis on individual rights than on collective responsibility, much domestic and European legislation may impact adversely on the operational effectiveness of the Army."

39 See e.g. the remarks of Patrick Mercer, cited in Sean Rayment, "British Troops in Iraq are Afraid to Open Fire, Secret MoD Report Confirms” The Telegraph (29 April 2006), online: The Telegraph <http://www.telegraph.co.uk/news/uknews/1517035/British-troops-in-iraq-are-afraid-to-open-firesecret-MoD-report-confirms.html>.

40 See e.g. Max Hastings, “The Army’s Deadliest Enemy is at Home” The Telegraph (21 January 2006), online: The Telegraph <http://www.telegraph.co.uk/comment/3622518/The-Army\%27s-deadliestenemy-is-at-home.html>; “Ministers 'Not Fit to Polish Boots' of Cleared Iraq War Hero” Daily Mail (15 February 2007), online: Mail Online <http://www.dailymail.co.uk/news/article-436175/Ministers-fitpolish-boots-cleared-Iraq-war-hero.html>.

41 Audrey Gillan \& Richard Norton-Taylor, “Angry Soldiers Demand ‘Trade’ Federation” The Guardian (26 January 2006), online: The Guardian <http://www.guardian.co.uk/uk/2006/jan/26/military. immigrationpolicy>. W.G.L. Mackinlay, "Perceptions and Misconceptions: How are International and UK Law Perceived to Affect Military Commanders and Their Subordinates on Operations?” (2007) 7 Defence Studies 111. Ibid. at 127.

Ibid.

Ibid. at 134 .

Ibid. at 135 . 
been given.” ${ }^{47}$ This should not be surprising. After all, law is one of the things that distinguishes war fighting from murder (important to morale and the professional ethos), affords individual soldiers some protection from capricious or arbitrary punishment from their superiors (or the enemy if captured), and ultimately supports operational effectiveness. With respect to operational effectiveness, it is a well-established point, but one worth repeating, that an effective system of military law is crucial to discipline and supports the chain of command. ${ }^{48}$

\section{THE ENCIRCLERS}

Many of the examples used in this article deal with international law. However, it is worth noting that this branch of law is often regarded within the military as only part of a bundle of civilian or civilian-inspired law and regulation that is oppressively, or at least confusingly, applicable to the armed services. In the British military, the encirclement is perceived to come from a variety of domestic, European, and international sources. Furthermore, this encirclement does not only take the form of law acting on the military from other sources, but has permeated the military's “own” law in matters such as discipline. According to the encirclement accounts, domestic regulatory schemes on health, safety, and labour standards, among other things, are applied inappropriately to the military. Particular invective is reserved for the unsuitable application of human rights standards in matters such as recruitment and discipline, which, it is argued, erode the distinct military norms intended to save the lives of soldiers on the battlefield and allow battles to be won. Thick, civilian regulation of the armed forces by Westminster or scrutiny from foreign cities such as Brussels, Strasbourg, or Geneva, is anathema to both operational requirements and the military ethos.

The importation of civilian norms through legalization happens not only through regulatory creep, but through increasing litigiousness as well. Often this litigation is brought by civilians or civilian employees of the Ministry of Defence (MoD), which the Ministry places in the context of concerns about a rising "compensation culture" generally. ${ }^{49}$ Thousands of service people or ex-service members have also claimed against the MoD for physical or psychological harm suffered during service. They are joined by increasing numbers of foreign civilians bringing suits in British courts and alleging harm at the hands of the British military overseas. Thus, legal siege comes from below (service people), as well as from above (governments), and the outside (civilians, both citizens and foreigners). Needless to say, the costs of these claims, both in terms of money paid out and time, detract from defence priorities. These legal challenges, it should be noted, also garner negative media attention, which detracts from the military’s ability to stay “on message.”

In addition to court challenges, collateral attacks on military decision-making occur through legal fora such as coroners’ courts. Recent coroners have, for example, investigated

$47 \quad$ Ibid. at 146.

48 See His Honour Judge James W. Rant, Courts-Martial, Discipline, and the Criminal Process in the Armed Services, 2d ed. (Oxford: Oxford University Press, 2003) at 1-20.

49 U.K., Ministry of Defence (MoD), Claims: Annual Report 2005/2006 (July 2006) at 2, online: MoD <http://www.mod.uk/NR/rdonlyres/5A077EA5-2E36-415B-9F1A-15EC0BEC094B/0/claims_ annual_report_0506.pdf $>$. 
inadequate military kits and death from "friendly fire" and subjected the military to serious and public criticism. ${ }^{50}$ Finally, quasi-judicial responses, notably independent public inquiries, have been urged upon the military over military failings. In May 2008, such an inquiry was ordered into the 2003 beating death of Iraqi civilian Baha Mousa by British troops, ${ }^{51}$ and the inquiry into the 1972 Bloody Sunday in Northern Ireland, which sat between 1998 and 2004, and which at the time of writing had still not delivered a report, shows that scrutiny of military action in a legal forum may take place long after the events in question. ${ }^{52}$ Indeed one of the fears about encirclement is that legal attacks can come from any place at any time.

As suggested in the survey of British military officers mentioned above, the overwhelming international law source of concern is international criminal law. Since the U.K.'s ratification of the 1998 Rome Statute of the International Criminal Court, ${ }^{53}$ the prospect of British soldiers being found responsible for war crimes has been seen as very real. There are fears that soldiers now hesitate to do their jobs, thus risking themselves, comrades, and the mission. ${ }^{54}$ Men and women in uniform are worried about being second-guessed by investigators and a legal system not only ignorant of the situation on the ground in Iraq or Afghanistan, but possibly "out to get them." One concern is that prosecutions may be launched to showcase the country's firm determination to punish war crimes and/or avoid ICC intervention under the Rome Statute's "complementarity" principle, under which the ICC can only assume jurisdiction over a case if the domestic legal system is unwilling or unable to investigate, prosecute, or try a case. ${ }^{55}$ Other concerns about international law are the extent to which human rights law applies to the actions of British soldiers overseas, the suitability of an outdated international humanitarian law regime for modern conflicts, and limits on the jus ad bellum, or the legality of the use of force itself.

The ICC remains a cause for concern in the U.S. as well despite that country's absence as a party to the Rome Statute. Some American military and academic observers have even suggested, as far fetched as this may be, that the ICC has the potential to be used by terrorists to further their aims, through misusing the Court's investigative powers, filing spurious complaints, and using the court process to manipulate the mass media. ${ }^{56}$ Intriguingly, despite Canada being the first country to adopt comprehensive legislation implementing the Rome Statute, no similar public hand-wringing over the ICC has taken place. Obviously, this is in part due to Canada's less ambitious role overseas but, as I will suggest later, the Canadian Forces have more or less come to accept the idea of external legal oversight and accountability from a variety of actors.

50 See e.g. “MoD Criticised for Soldier Deaths” BBC News (15 February 2008), online: BBC News <http:// www.news.bbc.co.uk/2/hi/uk_news/england/7245533.stm>; Michael Evans, "US agrees to Hand Over Video of Attack on British Convoy" The Times (7 February 2007), online: Times Online <http:// www.timesonline.co.uk/tol/news/world/us-and-americas-article1343485.ece>.

51 Richard Norton-Taylor, “MoD Launches Inquiry into Iraqi’s Death in Army Custody” The Guardian (14 May 2008), online: The Guardian <http://www.guardian.co.uk/uk/2008/may/14/military.iraq>. See online: The Bloody Sunday Inquiry <http://www.bloody-sunday-inquiry.org.uk/>.

17 July 1998, 2187 U.N.T.S. 3 (entered into force 1 July 2002, ratified by U.K. 4 October 2001) [Rome Statute].

Rayment, supra note 39.

Rome Statute, supra note 53, art. 17.

W. Chadwick Austin \& Antony Barone Kolenc, "Who’s Afraid of the Big Bad Wolf? The International Criminal Court as a Weapon of Asymmetric Warfare” (2006) 39 Vand. J. Transnat’l L. 291. 


\section{LAWFARE AND THE LIMITS OF OVERSIGHT}

The lawfare and encirclement notions are "catchy" and paradigmatic. They are also fundamentally misleading, suggesting as they do the image of a military isolated and surrounded by the enemy forces of civilianized and/or foreign law wielded by enemies or misguided compatriots acting under the guise of civilian oversight. This section of the article makes three points to highlight the shortcomings of the lawfare and legal encirclement metaphors. First, with historical perspective, it is clear that for centuries military law has been distinct, but evolving parallel to and under the influence of civilian law and civilian lawyers - civilianization is not a new and dangerous phenomenon. Second, the branch of international law that does set some limits on the means and methods of warfare, IHL, is fundamentally permissive. Third, domestic, regional, and international courts and tribunals remain deferential to the military's core function of combat, perhaps unduly so given the important role they play in democratic societies generally.

\section{A. Civilianization AND ITS BENEFITS}

Democratic civilianization is an old and constant theme in the military histories of the U.K., U.S., and Canada. ${ }^{57}$ While in the earliest days of raising armies, military law (Ordinances and later Articles of War) was purely the king's prerogative, since at least 1627 Parliament began limiting the power of the royal prerogative in defence matters. Eventually, with the promulgation of legislation in the late nineteenth century, the British military justice system passed from being partly statutory and partly prerogative to being wholly statutory, and civilian supremacy became enshrined. As well as overall civilian supremacy, the role of civilians in military justice has also expanded over the centuries. In 1688 the Articles of War referred to a Judge Advocate General (JAG) for the first time; a civilian who was to assist at courts martial on points of law. The JAG's powers steadily increased, at one point including prosecuting and advising the court martial, and today the position in the U.K. (though not in Canada or the U.S.) remains one held by a civilian. It would be wrong to see this evolving civilianization of military law as causing a steady erosion of operational effectiveness. To the contrary, for example, the Mutiny Act, 1688 made provision for "a more Exemplary and speedy Punishment than the [usual] Forms of Law will allow." ${ }^{2}$ There have of course been periods where civilianization has slowed and certainly the rate and extent of civilianization has been uneven in military history throughout the Western world. ${ }^{59}$ For example, while the British military justice system has been regularly tweaked by legislators and courts in recent years, ${ }^{60}$ congressional silence on post-war American military justice has

See generally Gordon Hook, "The Evolution of New Zealand Military Tribunals: From Prototype to Paradigm” (2003) New Zealand Armed Forces Law Review 36.

58 Mutiny Act, 1688 (U.K.), 1 Will. \& Mar., c. 5.

59 On the fits and starts of civilianization in French military justice, see Gérard Bonnardot, "Perspective historique du régime juridique des militaires en France” in Varenne, supra note 5, 165.

60 See e.g. Armed Forces Act 2006 (U.K.), 2006, c. 52. 
been notable. ${ }^{61}$ Nonetheless, the gradual march of civilianization over time is apparent in both the U.K. and the U.S. ${ }^{62}$

Having suggested that civilianization has always been present in the evolution of military law, it must be acknowledged that civilianization has been stepped up a notch in recent years, at least in the U.K. Military law expert Gerry Rubin suggests that starting in the mid-1960s, traditional British understandings of military legal autonomy began to give way to civilianization at a greater rate. This involved a change in military law and values as the military responded to wider social and legal norms, such as equal opportunities. He writes that now "military law and civilian law are intersecting on a wider front in domestic law and at greater frequency than hitherto." 63 He also notes in terms of actors that "military law has ceased to be the narrow preserve of military lawyers and of a handful of civilian lawyers who occasionally appeared before courts martial."64 Some of the civilianization that occurred since the mid-1960s was consensual. However, in the late 1990s at least, there were several ECHR challenges to the military, including one against the ban on gays and lesbians, and others to the independence and fairness of court martial procedures. These challenges resulted in change being forced on the military, not by the civilian executive or Parliament, but by courts. ${ }^{65}$ Interestingly, despite the lack of consensual change and indeed outright opposition to these changes, now it is difficult to find serving personnel who believe the end of the ban on gays and lesbians has hampered operational effectiveness or that greater reliance on a civilian judge advocate has undermined military justice.

Conceding that some changes have been imposed on the military by courts, it would nonetheless be wrong to leave the impression that this is the norm. Civilian-military interaction and engagement, rather than imposition and encirclement, remains the usual pattern. A good example of the usual interaction is the drafting of the Armed Forces Act 2006 in the U.K. Rather than the Act being externally imposed upon the military, the legislation was drafted in close consultation with the military. The Armed Forces Bill Team at the MoD included two representatives from each service and consulted "a cross section of personnel of all ranks in UK armed forces units" and took into account "the most recent operational experiences."66 The main purpose of the Act was to replace the three services' discipline acts with a piece of legislation that harmonizes to a large extent military discipline between the services. Rather than erode discipline in the armed forces by replacing the special relationship between commanders and his/her subordinates, the Act actually slightly

61 For a critique of the Uniform Code of Criminal Justice, see Michael I. Spak \& Jonathon P. Tomes, “Courts-Martial: Time to Play Taps?” (1999) 28 Sw. U.L. Rev. 481.

62 In the United States, private contractors were recently brought into the scope of the Uniform Code of Military Justice by U.S., Bill H.R. 5122, John Warner National Defence Authorization Act for Fiscal Year 2007, 109th Cong., 2006, s. 551.

63 G.R. Rubin, “United Kingdom Military Law: Autonomy, Civilianisation, Juridification” (2002) 65 Mod. L. Rev. 36 at 36-37. Several of the U.K.'s traditional allies faced similar pressures around the same time. For an Australian perspective, see Matthew Groves, "The Civilianisation of Australian Military Law" (2005) 28 U.N.S.W.L.J. 364.

$64 \quad$ Rubin, ibid. at 36.

65 See Lustig-Prean v. United Kingdom (2000), 29 E.H.R.R. 548; Smith v. United Kingdom (2000), 29 E.H.R.R. 493; Findlay v. United Kingdom (1997), 24 E.H.R.R. 221.

66 U.K., Armed Forces Bill Team, An Overview of the Service Justice System and the Armed Forces Act 2006 (U.K.: Minister of Defence, 2006) at 7-8, online: MoD <http://www.mod.uk/DefenceInternet/ AboutDefence/CorporatePublications/LegalPublications/ArmedForcesAct2006/>. 
increases the power of Army and Air Force commanders, albeit with a minor reduction in the powers of commanders at sea.

The longstanding theoretical debate over the extent to which a civil-military gap between military/warrior values and civil society/civilian values is inevitable, necessary, or desirable has been implicit in this discussion of civilianization and military-civilian engagement. To recap from Part II of this article, the two classic, opposing works in the field are Huntington's The Soldier and the State and Janowitz's The Professional Soldier. Huntington advocates maximizing the professionalism of the officer corps by establishing an autonomous military sphere while Janowitz argues for a military along the lines of a "constabulary” model, where the military maintains close links to society ${ }^{67}$ The debate remains a live one, but what is now clear to most is that the divide between the military and civil society cannot become a divorce. A certain degree of civilian and military comity must be maintained for the sake of the health of a particular society, democracy, and military. There is even one school of thought that suggests a direct relationship between democracy and military success. Facing empirical studies that show democracies win wars more often than other types of regimes, theorists have asked why this should be the case. Several factors appear to be at play. At the leadership level, strategic decisions may be sounder after being forced through the ringer of democratic debate. But even on the lower level of unit effectiveness it appears that importation of democratic norms into the military, such as respect for individuals and individual initiative-taking, results in better war fighting and effectiveness in other types of operations, such as occupation, as well. ${ }^{68}$

One consistent flashpoint for resistance to the importation of democratic values into the military, however, tends to be human rights. In what appears to be the only monograph on the subject, Peter Rowe suggests in The Impact of Human Rights Law on Armed Forces that human rights are compatible with effective military discipline. ${ }^{69}$ They do not, he argues, impose "an unacceptable burden" on the military. ${ }^{70}$ While praising Rowe's work, Rubin suggests that the question unanswered by Rowe is whether or not human rights "[result] in greater military effectiveness." "11 There is evidence to say that they may. In Britain's volunteer military of "citizen soldiers," where recruiting and retention, especially for the army, has become a challenge, the military cannot afford for the gap between civilian and military values to grow too wide. ${ }^{72}$ Rowe suggests, for example, that "[a]n army which declared that it would ignore the human rights of its soldiers during its disciplinary procedures may find it difficult to recruit and retain them where it depends upon voluntary

$67 \quad$ Huntington, supra note 8; Janowitz, supra note 9.

68 A good discussion of the democracy factor in military performance is Stephen Biddle \& Stephen Long, “Democracy and Military Effectiveness: A Deeper Look” (2004) 48 J. Confl. Resolution 525.

69 Peter Rowe, The Impact of Human Rights Law on Armed Forces (Cambridge: Cambridge University Press, 2006).

70 Peter Rowe, “Do Soldiers Really Have to Apply Human Rights Law in Military Operations?” (The 4th Ruth Steinkraus-Cohen International Law Lecture delivered to the United Nations Association, Westminster Branch, 16 May 2006) at 17, online: United Nations Association: Westminster Branch <http://www.unawestminster.org.uk/pdf/peter_rowe_lecture_2006.pdf>.

71 Gerry Rubin, Book Review of The Impact of Human Rights Law on Armed Forces by Peter Rowe, (2007) 12 J. Confl. \& Sec. L. 149 at 150.

72 On the importance of fairness in the disciplinary process for voluntary enlistment, see Rowe, supra note 69 at 68 . 
enlistment."73 Recruiting and retention aside, compliance with human rights and humanitarian law, and more generally, oversight by a variety of civilian actors including courts is also necessary to operational success, as will be further discussed below.

\section{B. THE WEAK CHECK OF INTERNATIONAL HUMANITARIAN LAW}

Concerns have been expressed that complying with decades-old IHL conventions in places like Iraq or Afghanistan, where the Western Alliance's enemies are unrestrained by morals or laws, has forced soldiers to fight "with one hand tied behind their back." While it is of course true that IHL places limits on the means and methods of warfare, the law remains essentially permissive. As the British MoD Manual of the Law of Armed Conflict puts it, " $[t]$ he law of armed conflict is consistent with the economic and efficient use of force. It is intended to minimize the suffering caused by armed conflict rather than impede military efficiency."74 This overriding theme in IHL is highlighted in the principle of military necessity. According to the MoD manual, which is intended to be an operational guide, "the use of force in ways which are not otherwise prohibited is legitimate if it is necessary to achieve, as quickly as possible, the complete or partial submission of the enemy." 75 There are, of course, grey areas in the concept of military necessity. Proportionality in balancing between the principles of humanity, and distinction between civilians and combatants on the one hand and military necessity on the other, is not always easy in targeting decisions, but the law accepts, among other things, that non-combatants may be killed in operations against the enemy. ${ }^{76}$

Where the substance of IHL has appeared outdated to governments and militaries, ways have been found to avoid awkward aspects of the law. One obvious way of doing so on the ground has been the use of private military companies (PMCs) who are, at least in a functional sense, not subject to the same checks as state militaries. ${ }^{77}$ At a higher level, United Nations Security Council resolutions and human rights norms have been used to justify what might otherwise be illegal. A prime example is the use of Security Council resolutions to justify the coalition's "transformative" actions in Iraq. These actions, including "debaathification," forced democratization, and federalization, were strictly contrary to "conservationist" principles of the law of occupation, which provide that existing structures of authority and laws must be left in place to the extent compatible with military exigencies. ${ }^{78}$ Security Council resolutions, notably Resolution 1483, in legalizing or at least legitimating the Coalition Provisional Authority (CPA), provided a structure to avoid traditional

$73 \quad$ Ibid

$74 \quad$ UK Ministry of Defence, The Manual of the Law of Armed Conflict (Oxford: Oxford University Press, 2004) at 21.

Ibid. at 22.

76 For an excellent account of the limits of IHL to control force, especially the intensity of force, see Jan Klabbers, "Off Limits? International Law and the Excessive Use of Force” (2006) 7 Theor. Inq. L. 59. I am not suggesting "dirty work" is the only reason for the use of PMCs, many of which are involved in logistics rather than combat: see generally Lindsey Cameron, "Private Military Companies: Their Status Under International Humanitarian Law and its Impact on their Regulation” (2006) 88 Int'l Rev. Red Cross 573.

78 See Adam Roberts, “Transformative Military Occupation: Applying the Laws of War and Human Rights” (2006) 100 A.J.I.L. 580 at 580. 
understandings of occupation law. ${ }^{79}$ Among other things, the Resolution authorized a UN special representative for Iraq to work with the CPA in "promoting the protection of human rights" and "encouraging international efforts to promote legal and judicial reform." ${ }^{80}$ While the Security Council's aim of promoting democratization is laudable, there are few who would suggest that implementation of the Resolution was done in a manner that respected the rule of law.

Of course, IHL continues to develop from its 1949/1977 bedrock instruments, the Geneva Conventions $^{81}$ and their Additional Protocols, ${ }^{82}$ and newer developments, such as the landmines or cluster munitions bans, can and do constrain the scope for military action. Furthermore, civilian norm entrepreneurs are involved in IHL to a greater extent now than at any time since the nineteenth century civilian efforts establishing the Red Cross movement; IHL is no longer "owned" by the military in the same way as it was at some points in the twentieth century. However, military realities are consistently taken heavily into account when negotiating or ratifying new IHL instruments and the protections extended to victims of armed conflict are developed incrementally. Military technical and legal experts are almost always consulted, as suggested by the interaction (over encirclement) paradigm put forward above. As one IHL expert puts it, "[s]tates are reluctant to give up anything that gives them a military advantage, so the search is always for common ground where states can agree on some measures that can afford a little protection for the victims of war." 83

Moving beyond a normative understanding of the doctrine of military necessity, it should also be pointed out that compliance with IHL brings military and political advantage. Troops who are IHL compliant will have a better chance of pacifying or occupying an area. Thus, it is often considered "politic" as well as mandatory to "enforce good behaviour upon occupying troops or upon soldiers who are dealing with a civilian population." ${ }^{4}$ This is particularly true in dealing with insurgencies and the need to win a "hearts and minds" campaign with the civil population. This was the case with the British army's experiences in Northern Ireland over many years. Some of the least successful aspects of the military's engagement in Northern Ireland came when, as has been ably demonstrated with respect to the 1970 Falls Curfew, the military acted on dubious legal grounds. ${ }^{85}$ The same is true today in Afghanistan and Iraq where breaches of IHL have been one cause of poisoned relations with local counterparts and a significant factor in losing or winning the peace following

SC Res. 1483, UN SCOR, 2003, UN Doc. S/RES/1483.

Ibid. at para. 8 .

Geneva Convention for the Amelioration of the Condition of the Wounded and Sick in Armed Forces in the Field, 12 August 1949, 75 U.N.T.S. 31; Geneva Convention for the Amelioration of the Condition of the Wounded, Sick and Shipwrecked Members of Armed Forces at Sea, 12 August 1949, 75 U.N.T.S. 85; Geneva Convention Relative to the Treatment of Prisoners of War, 12 August 1949, 75 U.N.T.S. 135; Geneva Convention Relative to the Protection of Civilian Persons in Time of War, 12 August 1949, 75 U.N.T.S. 287.

Protocol Additional to the Geneva Conventions of 12 August 1949, and Relating to the Protection of Victims of International Armed Conflicts (Protocol I), 8 June 1977, 1125 U.N.T.S. 3 [Protocol I]; Protocol Additional to the Geneva Conventions of 12 August 1949, and Relating to the Protection of Victims of Non-International Armed Conflicts (Protocol II), 8 June 1977, 1125 U.N.T.S. 609.

A.P.V. Rogers, Law on the Battlefield, 2d ed. (Manchester: Manchester University Press, 2004) at 3. Rant, supra note 48 at 2.

Colm Campbell \& Ita Connolly, “A Model for the 'War Against Terrorism'? Military Intervention in Northern Ireland and the 1970 Falls Curfew” (2003) 30 J.L. \& Soc’y 341. 
active hostilities. As Adam Roberts has put it, "Some of the biggest coalition problems in both Afghanistan and Iraq have come from failures of the coalition to observe basic norms on certain matters, especially with regard to treatment of prisoners." ${ }^{\text {86 }}$ It should be conceded that this instrumental argument about the utility of legal compliance is less obvious outside of the occupation/insurgency context. However, even "high intensity" conflicts may be fought parallel or prior to counter-insurgency operations and it is a feature of modern war that it is difficult to isolate one form of warfare from another. ${ }^{87}$ Furthermore, in any sort of conflict where the goal is a lasting accommodation or peace, IHL compliance plays an instrumental role. One of the reasons why the U.K. and Argentina were able to quickly restore relations following the Falklands conflict was the general compliance with IHL by both parties to the conflict.

\section{COURTS ARE DEFERENTIAL TO WAR Fighting}

The importance of the judicial branch to good governance, the rule of law, and democracy is well-established. However, with respect to national security matters, including defence, courts in democracies have tended to be deferential towards the executive and national security agencies. This is especially true in times of perceived emergency, which would

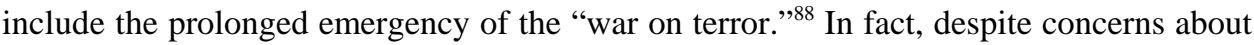
legal encirclement and lawfare, national and international tribunals pay great heed to the military’s operational prerogatives.

One high-profile issue before the courts has been the reach of national human rights protections beyond the territory of the state sending troops abroad. In Europe the question concerns the application of the ECHR beyond the member states of the Council of Europe. ${ }^{89}$ In the seminal case of Bankovic v. United Kingdom, families of those killed in Belgrade in 1999 by a NATO air strike on a communications site sought to bring claims before the Strasbourg court. ${ }^{90}$ Their claim was rejected. The approach taken by the Grand Chamber of the European Court of Human Rights was to construe narrowly the possibility of the ECHR applying extraterritorially. The Court emphasized the regional nature of the Convention, holding that it was "not designed to be applied throughout the world, even in respect of the conduct of contracting states." 91 The Court provided for some exceptions to this principle, such as the actions of embassies, but these were of limited scope.

Richard Norton-Taylor \& Clare Dyer, “International Laws Hinder UK Troops — Reid” The Guardian (4 April 2006), online: The Guardian <http://www.guardian.co.uk/politics/2006/apr/04/uk.military>. See Charles C. Krulak, “The Strategic Corporal: Leadership in the Three Block War” Marines 28:1 (January 1999) 26.

See David Dyzenhaus, The Constitution of Law: Legality in a Time of Emergency (New York: Cambridge University Press, 2006).

On the extraterritorial application of the 1966 International Covenant on Civil and Political Rights, 16 December 1966, 999 U.N.T.S. 171 [ICCPR] to non-nationals of states party to the Convention (which include Canada), see P.R. Ghandhi, The Human Rights Committee and the Right of Individual Communication: Law and Practice (Aldershot: Ashgate, 1998) at 129-32. See also UN Human Rights Committee, General Comment No. 31 [80]: Nature of the General Legal Obligation Imposed on States Parties to the Covenant, 80th Sess., UN Doc. CCPR/C/21/Rev.1/Add.13 (2004) at para. 10 [General Comment 31]. Bankovic v. United Kingdom (2007), 44 E.H.R.R. SE5 [Bankovic]. Ibid. at para. 78 . 
Subsequent jurisprudence from Strasbourg has been more equivocal. In Issa v. Turkey, the Court considered a claim resulting from the death of a number of shepherds in northern Iraq following an alleged Turkish military action over a six-week period. ${ }^{92}$ The Court appears to have expanded the Bankovic principle by suggesting that: "[A] state may also be held accountable for violation of the Convention rights and freedom of persons who are in the territory of another state but who are found to be under the former state's authority and control."93 If indeed the Issa test is the law, the possibility of human rights applying to the actions of British troops operating overseas is more likely than under the Bankovic reasoning. This Issa approach, however, has been derided as bad law by the House of Lords in the recent $R$. (on the application of Al-Skeini and others) $v$. Secretary of State for Defence decision, which involved the application of Convention rights (via the Human Rights Act) to British troops in Iraq. ${ }^{94}$ In that case, Lord Rodger said this of Issa, in what can only be intended as a blunt message to Strasbourg:

Without further guidance from the European court, I am unable to reconcile this approach with the reasoning in Bankovic. In these circumstances, although Issa concerned Turkish troops in Iraq, I do not consider that this aspect of the decision provides reasoned guidance on which the House can rely when resolving the question of jurisdiction in the present case. ${ }^{95}$

The Al-Skeini case stemmed from the intentional or accidental shooting deaths of five Iraqi civilians in 2003 in Basra during patrols by British troops and the beating to death of an Iraqi civilian while in British custody. The House of Lords accepted that the death of the civilian in custody could trigger Convention rights, as the fact of custody could represent a justifiable exception to the general principle on territorial jurisdiction of the ECHR (along the lines of embassy action). However, it roundly rejected the prospect of English courts having jurisdiction over the shooting deaths of the other five Iraqis killed in action. The result of the Law Lords' decision is that fighting operations are unreviewable by British courts on human rights grounds, essentially blocking Iraqi civilians from the protection of the Human Rights Act and the ECHR rights that the Act imports.

It should be pointed out that even if the House of Lords had accepted the Issa test, it is by no means certain that Basra in 2003 could have been viewed as being under British "authority and control” (and certainly not "effective control” as it has been put elsewhere in the Strasbourg jurisprudence, including in Issa itself). Indeed the lower courts in Al-Skeini, based on testimony from senior British officers, accepted that Basra had not been under the U.K.'s "effective control" due to the great amount of disorder. ${ }^{96}$ This is despite the fact that the U.K. was an occupying power for the purposes of IHL at the time.

This judicial reticence is found on the other side of the Atlantic as well. Indeed, a 2008 case in Canada rejected the possibility that the Charter applied to the actions of Canadian troops overseas. In Amnesty International Canada v. Canada (Minister of National Defence), Committee in General Comment 31, supra note 89, for the extraterritorial application of the ICCPR. [2007] UKHL 26, [2007] 3 All E.R. 685 [Al-Skeini]. 
two Canadian rights groups challenged the legality of the Canadian Forces detainee policy in Afghanistan. ${ }^{97}$ Specifically, they argued, turning over Afghans following Canadian capture to Afghan forces, where they faced a real prospect of torture and ill-treatment, contravened the freedom from torture as enshrined in the Charter. The Federal Court of Canada, however, held that the Charter did not apply to Canadian Forces' actions overseas, at least when they were deployed with the consent of the Afghan government and were not occupying forces. ${ }^{98}$ In this light the courts would not force the Charter to "follow the troops" without the specific authorization of Afghanistan; an authority that the host state has not given. The Court noted that Afghan civilians have the protection of IHL generally and by virtue of an agreement between Canada and Afghanistan, though that is perhaps cold comfort in light of the current near impunity in Afghanistan over prisoner abuse. Finally, although one can point to the halting and incremental constitutional supervision by the U.S. Supreme Court over government action at Guantanamo, it is worth bearing in mind, as stressed by the justices in the June 2008 Boumediene v. Bush decision, which held that the detainees had a habeas corpus right before federal civilian judges, that much hinged on the fact that the U.S. base is effectively American soil in light of over 100 years of "complete and uninterrupted control." 99 American detention of Iraqis in Iraq, for example, is very likely beyond the scope of the Guantanamo jurisprudence and the supervision of the courts. Indeed, throughout the Guantanamo saga the Court has gone to great lengths to ensure that its actions do not "hamper the war effort and bring aid and comfort to the enemy," suggesting that Guantanamo was reviewable in part because the prolonged detention far away from the battlefield went beyond the exigencies of military necessity. ${ }^{100}$ Indeed, the Guantanamo jurisprudence does little to depart from a long line of jurisprudence displaying deference to both the war powers of the commander-in-chief and the military's own definition of its operational boundaries. ${ }^{101}$

The courts have prevented victims of war from successfully claiming human rights violations in other ways as well. These include invoking notions such as the non-justiciability of vital national security matters, ${ }^{102}$ a "margin of appreciation" for states engaged in military action, ${ }^{103}$ and reliance on Security Council resolutions. A good example of judicial reluctance to overstep bounds can be found in the cases of Behrami v. France and Saramati v. France, which involved, respectively, the failure of French Kosovo Force (KFOR) troops to mark/

2008 FC 336, 292 D.L.R. (4th) 127 [Amnesty]. Though the correctness of this case is in doubt since the decision of the Supreme Court of Canada in Khadr v. Canada (Minister of Justice), 2008 SCC 28, [2008] 2 S.C.R. 125, wherein the Court stressed that the normal principle that the Charter does not apply abroad does not extend to actions which violate Canada's international human rights obligations. Amnesty, ibid. at para. 184.

128 S. Ct. 2229 at 2258 (2008).

Rasul v. Bush, 542 U.S. 466 at 499 (2004).

Most infamously with respect to executive powers, see Korematsu v. United States, 323 U.S. 214 (1944) (approving a military order removing Japanese Americans from parts of the west coast during World War II). In terms of the deference to the military itself, see Goldman v. Weinberger, 475 U.S. 503 (1986) (Air Force could restrict the religious freedom of a Jewish officer who sought to wear a yarmulke). In the latter case the Court said, "courts must give great deference to the professional judgment of military authorities concerning the relative importance of a particular military interest" (at 507). On the notion of non-justiciability, see Ariel L. Bendor, "Justiciability of the Israeli Fight Against Terrorism” (2007) 39 Geo. Wash. Int'l L. Rev. 149.

103 See e.g. the Varvarin Bridge decision from the German Federal Court of Justice for Civil Matters (BGH 2.11.2006, III ZR 190/05), which rejected compensation claims for German involvement in a NATO bridge bombing in the Kosovo conflict that killed ten civilians and injured 30 others. 
defuse a cluster bomb dropped in the 1999 NATO aerial bombardment in Kosovo and the illegal detention of a Kosovar by KFOR officers from European countries. The Grand Chamber of the European Court of Human Rights considered that when armed forces of Council of Europe states conduct operations under a Chapter VII mandate from the UN Security Council, the Court may not review those actions. ${ }^{104}$ Given the Security Council's lack of accountability, both in terms of a democratic deficit and with respect to other states in the international community, the lack of judicial scrutiny under the European rights regime is disconcerting. ${ }^{105}$ However, in a move that surprised many observers, the European Court of Justice recently signalled that it will not accept Security Council action as an excuse for the community's institutions trammelling individual rights and due process. In Kadi v. Council, the Court ruled that the community's courts have the jurisdiction to scrutinize “terrorist blacklisting” even when done in response to a Security Council resolution. ${ }^{106}$ While judicial review of international organizations raises conceptual problems - as noted above, the separation of powers paradigm does not easily map on to international law - a nascent trend in the law of international organizations towards accountability and control, on functional if not constitutional grounds, is perhaps discernable. ${ }^{107}$

Of course, human rights claims are not the only sort of claims that can be advanced against the military for its actions overseas. As noted above, tort actions, and particularly negligence actions informed by IHL, are also possible. However, in any case of active war fighting, "combat immunity” will generally protect the military from such actions. ${ }^{108}$ As the leading case puts it: " $[\mathrm{t}]$ o concede that any civil liability can rest upon a member of the armed forces for supposedly negligent acts or omissions in the course of an actual engagement with the enemy is opposed alike to reason and to policy."109

Emphasizing judicial deference to the core military function, however, should be placed in a more global context in terms of access to justice for those harmed by the military's actions. Specifically, review of foreign military actions will generally be prevented in the "host" state where the military operates. This will usually be done through Status of Forces Agreements (SOFAs), ${ }^{110}$ or, in the case of international administration of territory by the UN, through regulations from the Special Representative of the Secretary-General. In Iraq, Order 17 from the Coalition Provisional Authority provided that the multinational force would be

Behrami v. France (2007), 45 E.H.R.R. SE10; Saramati v. France (2007), 45 E.H.R.R. SE10. See also R. (on the application of Al-Jedda) v. Secretary of State for Defence, [2007] UKHL 58, [2008] 3 All E.R. 28.

For a discussion of the Council's accountability and legitimacy see David D. Caron, "The Legitimacy of the Collective Authority of the Security Council” (1993) 87 A.J.I.L. 552.

Kadi v. Council, C-402/05 P, [2008] O.J. C 285/2 (E.C.J.).

On the poor fit of the separation of powers doctrine in the international legal system, see Tomuschat, supra note 22. On moves towards accountability and control in the law of international organizations, however, see Jan Klabbers, "Straddling Law and Politics: Judicial Review in International Law" in Ronald St. John Macdonald \& Douglas M. Johnston, eds., Towards World Constitutionalism: Issues in the Legal Ordering of the World Community (Leiden: Martinus Nijhoff, 2005) 809.

Shaw Savill and Albion Company Ltd. v. The Commonwealth, [1940] HCA 40, 66 C.L.R. 344 [Shaw Savill]. See also Bici v. Ministry of Defence, [2004] EWHC 786 (QB), indicating that negligence claims are possible in a "policekeeping" context.

Shaw Savill, ibid. at 361.

Admittedly, SOFAs can also be theoretically framed as allowing accountability in sending states. 
"immune from Iraqi legal process." ${ }^{111}$ Calls to end this accountability gap that typically exists for local people, for example by appointing an ombudsman with jurisdiction over NATO or UN peacekeeping operations, have to date been rejected. Since 1999, KFOR forces in Kosovo have refused to accept the jurisdiction of the ombudsperson established by the UN administration there in 1999, despite having been engaged in policing/peacekeeping rather than combat. ${ }^{112}$

Turning to the question of criminal jurisdiction, fear of international or domestic prosecution for war crimes - and the attendant effect that it has on the willingness of troops to do their job properly - is a particular cause for concern in the encirclement camp, as suggested earlier. In testimony before the House of Commons' Select Committee on the Armed Forces Bill, Admiral Boyce put it this way:

[T]here is huge risk averseness out there and a worry about where people stand in law. If I can give an example of that, and it is a rather light-hearted example and a true story, a unit was doing training down in Lydd, which is where they do their training for going to Iraq so that they know how to cope with a dangerous situation on the ground where you might have civilians and you might have bad people, and a young soldier "shot" a good person and the sergeant instructor came up and said, "Right, lad. That's you for The Hague". That is the feeling out there. People feel under pressure. ${ }^{113}$

It has been well-established that the chances of a service member from a military and country with effective justice systems ever being tried at The Hague are remote. ${ }^{114}$ They argue that given the Rome Statute's complementarity principle, a fundamental breakdown in British justice would be required. The U.K. would have to have shown itself to be unwilling or unable to investigate, prosecute, or try cases of genocide, crimes against humanity, or war crimes on its own. This is, of course, not impossible, but highly unlikely. These arguments have been addressed elsewhere and need not be dwelt on here. ${ }^{115}$ Rather, another question presents itself. Is there, to avoid British soldiers being sent to The Hague, a greater move to try them at home under the British implementing legislation, the International Criminal Court Act 2001 ?116 $^{116 e r e ~ h a v e ~ b e e n ~ r e p o r t s ~ t h a t ~ s o l d i e r s ~ n o w ~ h e s i t a t e ~ t o ~ f i r e ~ t h e i r ~ w e a p o n s, ~}$ even in self-defence, for fear of legal prosecution. The number of prosecutions, however, simply does not provide a credible basis for the fear. The raw statistics produced by the military are telling. Between the Iraq invasion in 2003 and May 2006, “not one single soldier

Coalition Provisional Authority, CPA/ORD/27 June 2004/17, "Status Of The Coalition Provisional Authority, MNF - Iraq, Certain Missions and Personnel In Iraq” (27 June 2004) at 4, online: The Coalition Provisional Authority <http://www.cpa-iraq.org/regulations/20040627_CPAORD_17_ Status_of_Coalition_Rev_with_Annex_A.pdf $>$. Christopher P.M. Waters, “Nationalizing Kosovo’s Ombudsperson” (2007) 12 J. Confl. \& Sec. L. 139 at 144 .

113 U.K., House of Commons Select Committee on the Armed Forces Bill, Special Report of Session 200506, vol. 2 (London: Stationery Office, 2006) at 59.

114 See generally Marten Zwanenburg, "The Statute for an International Criminal Court and the United States: Peacekeepers under Fire?” (1999) 10 E.J.I.L. 124. Former Foreign Secretary Robin Cooke went so far as to say that "British service personnel will never be prosecuted by the International Criminal Court” (see U.K., H.C., Parliamentary Debates, vol. 366, col. 222 (3 April 2001)).

115 See generally James Sloan, "The International Criminal Court and Domestic Enforcement in Canada and the United Kingdom" in Christopher P.M. Waters, ed., British and Canadian Perspectives on International Law (Leiden: Martinus Nijhoff, 2006) 53. 
has been tried in court for firing his weapon, in a tactical context, on operations in Iraq." 117 Or, as the army's Adjutant General put it, "no single soldier has been prosecuted by the Army for a decision made in the 'agony of the moment." "118 Indeed, not only have there been no prosecutions arising from shootings, but investigations that have taken place are largely based on what shooters themselves, and the other people in their units, say. Perhaps given operational constraints this is the way it must be. But it does raise the question of why soldiers are concerned with being second-guessed for self-defensive actions that have not been fully allayed by commanders. To be clear, there have been abuse trials. The trial of a commanding officer, Col. Mendonca, and his men over the beating death of a detained Iraqi hotel clerk was well publicized. It, however, resulted in acquittals for all but one corporal who admitted inhumane treatment of a detainee. ${ }^{119}$ It was clear from the testimony of witnesses that a cover-up was taking place (events were largely "forgotten" by military personnel who had been present), or, as the judge put it, "a more or less obvious closing of ranks." 120 Thus, even in obvious abuse cases, out of the heat of combat, the military justice system alone can be an impotent force even in the case of obvious wrongdoing.

\section{RETHINKING Civil-Military RELATIONS: THE Role Of LAW}

Given my argument that concerns over lawfare and legal encirclement are largely misplaced, the question remains of why perceptions of encirclement exist. Several possibilities can be put forward, including the power of the encirclement metaphor itself, as well as the evocative language that has been used in the encirclement discourse (for example, the "ambulance chasers" charge levelled against British lawyers bringing claims against the MoD from Iraqi civilians ${ }^{121}$ ). There are more substantive reasons as well.

First, there are institutional tensions within the armed forces, between legal advisers and the military police on one hand, and "war fighters" on the other. While the role of the legal adviser is pitched within the armed forces as enabling commanders to do their job, some officers continue to see lawyers as constraining military logic. ${ }^{122}$ Furthermore, despite the high quality of legal officers in the military, there is the impression among some service people that lawyers are not "real" officers and indeed are not good lawyers either ("if they were good, they would be in a big law firm”). This view is distinctly on the wane, however,

F.R. Viggers, "The Military Criminal Justice System: Supporting Operational Effectiveness in the Military Environment” at 3, online: British Army <http://www.army.mod.uk/documents/general/ military_criminal_justice_system.pdf>.

Ibid. at 4.

See Mark Oliver, “Cleared Mendonca Quits Army” The Guardian (1 June 2007), online: The Guardian <http://www.guardian.co.uk/world/2007/jun/01/iraq.military>.

Raymond Whitaker, “The Victims of War: 93 Injuries, One Killing, No Justice” The Independent (18 March 2007), online: The Independent < http://www.independent.co.uk/news/uk/crime/the-victims- ofwar-93-injuries-one-killing-no-justice-440756.htm>.

See Jamie Doward, “Lawyers 'Besiege’ Army over Iraq Abuse” The Observer (24 July 2005), online: The Guardian <http://www.guardian.co.uk/uk/2005/jul/24/iraq.military>.

See U.K., Ministry of Defence, Legal Support to Joint Operations (Joint Warfare Publication 3-46) (Shrivenham: Joint Doctrine \& Concepts Centre, 2005) at 2-2:

The LEGAD [Legal Adviser] must provide robust advice against the potentially illegal options but also make clear the existence of any alternative approaches in the form of operational suggestions to the Comd [Joint Commander]. If he does this he will be seen as...someone who enables operations to proceed legitimately rather than someone who stifles tactical endeavour. 
as senior officers have stressed the usefulness of legal advisers in complex operations. ${ }^{123}$ Military police have also been resented in some military quarters. In other words, concerns about legal encirclement are sometimes as much about internal institutional politics and perceptions as hostility to civilian legal oversight. Perhaps nowhere is this more evident than in the case of the American military JAG officers who have been assigned to defend detainees at Guantanamo. They have robustly challenged the very legality of the military commission system, both before the courts and in the media, and in doing so have antagonized senior military officers and the civilian administration in Washington. ${ }^{124}$

Second, while I have argued that concerns about law leading to a reduction in operational effectiveness are misplaced, it is likely the case that legal issues arise more frequently than in the past, perhaps contributing to a sense of siege. In 2000, the editors of a special issue of International Organization suggested that a greater "move to law" was occurring and that a trend towards the "legalization of world politics" was taking place. ${ }^{125}$ While this view has been criticized as presenting a flat conception of law, ${ }^{126}$ it is likely the case that more time is spent on law by the military - even if in interacting with the law rather than being "encircled" by it - than before. The growing interaction with law is perhaps reflected in the fact that the number of legal advisers deployed overseas with British military units was at an all-time high with the 2003 Iraq invasion, and since the invasion (and a lessons learned exercise) military lawyers receive intensive training on "operational law" prior to deployment.

Third, legal misinformation is rife in the armed forces. This is well-illustrated by perceptions of the ICC and the U.K.'s domestic implementing legislation. Soldiers understand erroneously, for example, that the 2001 legislation has brought no changes (when in fact crimes against humanity were criminalized in the U.K. for the first time in the ICC $A c t$ ) or, alternatively, that there is a real danger of direct prosecution by the ICC. One obvious proposal to remedy the legal misinformation would be to deploy even higher numbers of legal advisers in the military (in the British army they are deployed to the Brigade level). Ultimately, however, this is not in itself a solution. While sufficient legal

For example, speaking at the launch of the U.K.'s Manual of the Law of Armed Conflict in 2004, the Deputy Chief of Defence Staff (Commitments), Lt. Gen. Robert Fry, said, "Legal Advice is essential at all levels and an awareness of the legal framework for operations is a crucial part of the Commander's professional understanding" (cited in ibid. at iii). William Glaberson, “An Unlikely Antagonist in the Detainees' Corner” The New York Times (19 June 2008), online: The New York Times <http://www.nytimes.com/2008/06/19/us/19gitmo.html>.

Goldstein et al., supra note 25 at 386. More generally see W.A. Bogart, Consequences: The Impact of Law and Its Complexity (Toronto: University of Toronto Press, 2002) at 5, who suggests that "[a] survey of the last five decades of Western industrialized society would highlight, as a defining element, the insinuation of law into all manner of human endeavour."

126 See e.g. Jutta Brunnée \& Stephen J. Toope, "International Law and Constructivism: Elements of an Interactional Theory of International Law” (2000) 39 Colum. J. Transnat'l L. 19 at 72, who suggest that the "legalization" view unwittingly accepts law as a binding, external force, without explaining where it comes from. By contrast, they argue for a focus on "the mutual generative normative activity of agents and structures in international law and politics." The view put forward in the present article that the military is a relevant actor in law creation, and is not merely acted upon by law, is informed by Brunnée and Toope's arguments. 
advice is needed, and indeed is obligatory under IHL, ${ }^{127}$ numbers will never be adequate to provide timely advice at all levels of decision-making. Furthermore, the absurdity of the army as a "deliberative body ... [which] ought to be composed of attorneys"128 has long been obvious. It is individual commanders, including small unit commanders (so called "strategic corporals”129), who must make quick operational decisions guided by their rules of engagement and basic legal principles, that will ultimately decide the success or failure of a mission. Accordingly, dissemination of legal information and comprehensive training in IHL and other relevant legal regimes across military trades and levels must be stepped up. While IHL is a dimension of military training in the U.K. from basic through to advanced officer training, it remains insufficient according to military personnel themselves. In the survey of military officers discussed above, less than 35 percent of those polled believed that military personnel receive adequate training on legal issues prior to being deployed on operations. ${ }^{130}$ Training has been found not only to allow soldiers to internalize what is being taught, but also to provide a psychological, or self-confidence boost. ${ }^{131}$ Accordingly, additional training on law may help alleviate concerns about encirclement and the consequent damage to morale that engenders. A focus on training will also place the emphasis on implementing law, which is a broader and more productive enterprise than simply enforcing it through penal sanction, as important as the latter task may be to implementation. ${ }^{132}$ In fairness, as highlighted by the British army's 2008 Aitken Report, IHL training has been increased in the last few years. ${ }^{133}$ In my view, however, this training remains inadequate in various branches of the Defence Academy.

IHL training is even less adequate in the U.S. Of the 1,767 troops questioned by a U.S. military mental health advisory team in 2006, 41 percent of soldiers and 44 percent of marines "believed that torture should be permitted if it would save the life of a fellow soldier or marine." ${ }^{34}$ Similarly, 36 percent of soldiers and 39 percent of marines "said torture should be allowed to extract important information about Iraqi insurgents.” ${ }^{135}$ Less than 47 percent of soldiers and 38 percent of marines "felt that non-combatants should be treated with dignity

Protocol I, supra note 82, art. 82, provides that parties "shall ensure that legal advisers are available, when necessary, to advise military commanders at the appropriate level on the application of the Conventions and this Protocol and on the appropriate instruction to be given to the armed forces on this subject." Note the latitude given in terms of numbers of legal advisers through the word "appropriate." Sir Charles Napier, in Charles M. Clode, The Military Forces of the Crown: Their Administration and Government (London: John Murray, 1869) vol. 2 at 152.

The term was coined by the American General Charles Krulak, supra note 87, to describe devolved responsibility on junior leaders in complex situations that include elements of traditional war fighting, but also peacekeeping and humanitarian activities. Mackinlay, supra note 42 at 125. See Hew Strachan, “Training, Morale and Modern War” (2006) 41 Journal of Contemporary History 211.

On the importance of focusing on implementation rather than enforcement, see Michael A. Meyer \& Hilaire McCoubrey, eds., Reflections on Law and Armed Conflicts: The Selected Works on the Laws of War by the Late Professor Colonel G.I.A.D. Draper, OBE (The Hague: Kluwer Law International, 1998).

U.K., Ministry of Defence, The Aitken Report: An Investigation into Cases of Deliberate Abuse and Unlawful Killing in Iraq in 2003 and 2004 (25 January 2008), online: MoD <http://www.mod.uk/NR/ rdonlyres/7AC894D3-1430-4AD1-911F-8210C3342CC5/0/aitken_rep.pdf> [Aitken Report]. 
and respect,” as required by IHL. ${ }^{136}$ Additional resources have been devoted to IHL training since then, but change will take time, and a cultural shift in thinking is required to move beyond the traditional emphasis on destruction of the enemy and enforce protection. ${ }^{137}$

Most importantly, perhaps, concerns about legal encirclement represent a failure of leadership and communication. Rather than disseminating genuine information, some senior officers have engaged in fear mongering about the ICC. Similarly, mixed messages have been given with respect to the term "war crimes," with some senior commanders arguing that the term refers exclusively to mass crimes, like those committed by the Nazis, and is inappropriately applied to the actions of individual British soldiers who have been accused of abuses in Iraq. The leadership gaps are not confined to military officers. For example, John Reid, then Britain's Secretary of State for Defence, asked for a rethink of the Geneva Conventions, stating, "[i]f we do not, we risk continuing to fight a 21st Century conflict with 20th Century rules." "138 To be fair, he also reiterated that U.K. troops must comply with the law, but the media message remained one of "outdated laws.” This kind of talk by serving ministers, coupled with an early failure in the "war against terrorism" by senior members of government to clamp down on questionable practices, such as hooding, ${ }^{139}$ sends out entirely the wrong signals to men and women in uniform, and to the public, about the need to consistently operate within the bounds of legality. Measures are now being taken in the British military to send a strong and consistent message regarding compliance with the law, as highlighted by the Aitken Report. ${ }^{140}$ Among many points, for instance, it highlights that sensory deprivation, including hooding, is illegal except where security demands it. Similarly, U.S. counter-insurgency doctrine (at least for the army and marines - the air force lags behind) now explicitly highlights the need to comply with the law of armed conflict and the strategic benefits of doing so. ${ }^{141}$ Whether these new leadership initiatives will make a difference remains to be seen.

While this article has focused primarily on the British and, to a lesser extent, American contexts, it is worth noting that following Canada's 1992-93 Somalia fiasco (which included the torture and killing of a young Somali by members of the Canadian Airborne Regiment), a wide-ranging public inquiry was held that found systemic failures in leadership and accountability in the Canadian Forces. ${ }^{142}$ Similar failures to those exhibited by the Canadian Forces in Somalia are apparent in the British and American militaries today as evidenced by the prisoner abuse scandals from Iraq. However, no similar, comprehensive, transparent, and independent — that is, civilian — review has taken place in the U.K. or the U.S. as it did in

$136 \quad$ Ibid.

137 The challenges facing the U.S. military in this regard are described in Nigel Aylwin-Foster, "Changing the Army for Counterinsurgency Operations” (2005) 85:6 Military Review 2.

138 John Reid, “20th-Century Rules, 21st-Century Conflict” (Speech delivered at the Royal United Services Institute for Defence, 3 April 2006), online: MoD <http://www.mod.uk/DefenceInternet/AboutDefence/ People/Speeches/SofS/2006040320thcenturyRules21stcenturyConflict.htm>. See Andrew Johnson, “MPs to Demand Inquiry into Abuse of Prisoners in Iraq” The Independent (1 July 2007), online: The Independent <http://news.independent.co.uk/uk/politics/article2725718.ece>. Aitken Report, supra note 133.

141 See e.g. The U.S. Army and Marine Corps Counterinsurgency Field Manual (Chicago: University of Chicago Press, 2007) at 347-60.

142 See Report of the Somalia Commission of Inquiry (Ottawa: Department of National Defence, 1997), online: Department of National Defence <http://www.dnd.ca/somalia/somaliae.htm>. 
Canada following Somalia. It is notable in Canada that the language of lawfare and encirclement is absent from discussions over civil-military relations, although, interestingly, "legal jihad" rhetoric has been used by other Canadian security agencies. ${ }^{143}$ To be clear, the military has vigorously litigated specific cases, including the transfer of Afghan detainees discussed above. In that case, for example, a top Canadian Forces commander made alarmist predictions in an affidavit before the Court considering the matter that serious tactical reverses would be suffered by the Canadian Forces if forced to suspend detainee transfers. ${ }^{144}$ Furthermore, the military has carefully tried to manage the release of information over its actions with respect to the detainees. Nonetheless, there is a general "cultural" consensus in the Canadian military that it must engage with and comply with IHL and other legal norms in whole measure. ${ }^{145}$ Indeed, at one point before the Federal Court gave its decision in Amnesty, the military itself suspended prisoner transfers due to a lack of credible assurances that transferees would not be tortured.

Related to the changed nature of Canada's military culture is the fact that institutional mechanisms put in place post-Somalia provide oversight of Canadian Forces' actions. Thus, for example, there is a Military Police Complaints Commission of Canada that is independent of the military and has the power to hold public investigations. ${ }^{146}$ This commission is currently holding an inquiry into military police handling of the detainees and has the power to subpoena witnesses. Similarly, a civilian ombudsman for the Canadian Forces was established in 1998. The ombudsman has a wide-ranging mandate to consider complaints from individual members of the armed forces and make recommendations to the Minister of Defence. The fact that he/she makes recommendations outside the military chain of command means that the command structure itself is not compromised while, nonetheless, serious grievances can be aired by ordinary soldiers, sailors, and airmen. The ombudsman does meet with "pockets of resistance" in the armed forces who oppose civilian oversight, but by and large has reported receptiveness to the institution's role. ${ }^{147}$ Ideally, the ombudsman strengthens the chain of command and indeed the armed forces. As the first ombudsman put it:

Giving members a voice and a quick, efficient means to solve problems reduces dissatisfaction, improves morale, and thereby reinforces the commitment of soldiers. After all, it is easier to take direction from a chain of command that is perceived to act fairly and reasonably than it is to blindly obey those who direct matters in a rigid or narrow-minded way by virtue solely of the force of their authority. ${ }^{148}$

Colin Freeze, “State Agents say Inquests Causing 'Judicial Terrorism”” The Globe and Mail (9 June 2007) A4.

Paul Koring, “Top Soldier Speaks out on Detainee Transfers” The Globe and Mail (19 December 2007), online: The Globe and Mail <http://www.theglobeandmail.com/servlet/story/RTGAM.20071219. wdetainee19/BNStory/Afghanistan/>.

Though I do not mean to suggest that cultural shifts in the military, including the post-Somalia changes, have happened without difficulty or have taken the same form in the military's various subcultures. See Allan D. English, Understanding Military Culture: A Canadian Perspective (Montreal: McGill-Queen's University Press, 2004).

See online: Military Police Complaints Commission <http://www.mpcc-cppm.gc.ca/> . National Defence and Canadian Forces Ombudsman, Overhauling Oversight: Ombudsman White Paper by André Marin (Ottawa: National Defence and Canadian Forces, 2005) at 4.

Ibid. at 12 . 
It is important to note that both the Military Police Complaints Commission and the ombudsman are civilian oversight mechanisms operating outside not only of the military chain of command, but also the executive's control. They ensure a democratic oversight and governance system for the military that is broader than the control of a handful of individuals in the executive who would otherwise have primary carriage of the oversight process. To return to the detainee transfer illustration, the Minister of Defence at the time saw nothing wrong with the transfer policy and even accused his parliamentary critics of failing to support the troops by pressing the matter. In the absence of other institutions, including the courts and quasi-judicial bodies, scrutiny of the Forces’ policy would have ended there.

The Somalia inquiry was damaging to the morale of the Canadian Forces and, at times, it seemed as if civilian commentators were deliberately "trashing" military values and traditions. This is undoubtedly due to a disregard for and lack of education about the need for armed forces in Canadian society at that time. ${ }^{149}$ However, without wholesale "soul searching" and a Canadian post-Somalia type institutional rethink — albeit one that might be more attune to military sensibilities - I am not convinced that there will be real change in the British or American militaries.

\section{CONCLUSION}

There is a perception in some quarters both within and outside the armed forces that the military is under attack through legal weapons, that it is subject to lawfare or legal encirclement. By contrast, this article suggests that the lawfare and legal encirclement metaphors are misleading. They obscure the balancing process that occurs between the need for distinct operational norms corresponding to the reality of military life, and the need to operate within evolving international and domestic norms. Furthermore, while it may well be the case that the military is interacting with law to a greater extent than before, the military's core function, expeditionary combat, has received a "soft touch" by the law. Thus, concerns about operational constraints are often misplaced. Several reasons can be put forward to explain the persistence of concerns about legal encirclement. One of the primary ones, however, is a failure of military and political leaders to send consistent, strong messages about the importance of compliance with the law, and more broadly, democratic governance. Ultimately, this failure will result not only in a betrayal of a value system that claims adherence to the rule of law and democracy, but can contribute to operational failure as well.

149 Joseph S. Nye, Jr., “Epilogue: The Liberal Tradition” in Larry Diamond \& Marc F. Plattner, eds., CivilMilitary Relations and Democracy (Baltimore: John Hopkins University Press, 1996) 151 at 153. Nye has argued that as part of the "liberal" democratic tradition of civilian control over the military, civilians have obligations towards the military as well: “[c]ivilians are required to 1) recognize that armed forces are legitimate tools of democratic states; 2) fund and respect properly developed military roles and missions; and 3) educate themselves about defence issues and military culture.” For at least a few decades between the close of the Korean war and the start of the current Afghanistan campaign, it is questionable whether Canadian society fulfilled the civilian "part of the bargain." 